\title{
'Pestilential Emanations', Medical Knowledge, and Stigmatisation in Saint-Louis, Senegal, 1854-1920
}

\author{
Kalala Ngalamulume
}

https://orcid.org/0000-0003-3867-0539

Byrn Mawr College, USA

\begin{abstract}
This article shows how French doctors based in Saint-Louis-du-Sénégal, the capital of colonial Senegal, conceptualised the Senegambian region as a diseased environment and Africans as carriers of infectious agents. It explains how perceptions of the hot tropical climate, combined with outbreaks of epidemic diseases and seasonal allergies, were instrumental in the processes of urban transformation through hygienic measures such as waste removal, the closing of cemeteries, and the imposition of new building codes. The article also shows how the stigmatisation of Africans was implicated in the forced removal of the urban poor - firstly from the city centre, and later from the entire cityisland. Colonial medical knowledge in Senegal was initially based on the miasma theory, however, germ theory was adopted in the aftermath of the 1900 yellow fever epidemic. Both theories, in relation with racialism, impacted the urban landscape in Saint-Louis, Senegal.
\end{abstract}

Keywords: Senegal, Saint-Louis, Colonial Africa, Yellow fever, epidemic diseases, forced removals, urban planning, urban poor, tropical climate

eTropic: electronic journal of studies in the tropics publishes new research from arts, humanities, social sciences and allied fields on the variety and interrelatedness of nature, culture, and society in the tropics. Published by James Cook University, a leading research institution on critical issues facing the world's Tropics. Free open access, Scopus Listed, Scimago Q2. Indexed in: Google Scholar, DOAJ, Crossref, Ulrich's, SHERPA/RoMEO, Pandora. ISSN 1448-2940. Creative Commons CC BY 4.0 free to download, save and reproduce. To cite, include: Author(s), Title, eTropic, volume, issue, year, pages and DOI: http://dx.doi.org/10.25120/etropic.20.1.2021.3792 
eTropic 20.1 (2021) Special Issue: Pandemic, Plague, Pestilence and the Tropics

\section{Epidemic Cities}

olonial cities - mostly situated in the world's Tropics - formed major links between Europe and its dependencies and were instrumental in articulating the flows of capital: commodities (exported raw materials and imported manufactured goods), people, cultural practices, tastes, and lifestyles. They became the "nerve centres" of colonial exploitation and the location for banks, agency houses, insurance and shipping companies. Colonial cities also served as social technologies with the power to control the local population through systems of classification and symbolic codes. Thus, the built environment of colonial cities reflected the division of the society along economic, social, racial, and cultural lines (King, 1990). Segregation was a complex process that took decades to implement and the authorities deployed several strategies (and their rationalisations) ranging from disease, to hygiene/sanitation, to lifestyles and building codes.

Taking into consideration the background of previous studies of urban segregation in Africa, this article narrows to a more specific goal to show how French doctors based in Saint-Louis-du-Sénégal, the capital and port city of colonial Senegal, conceptualised the Senegambian region as a diseased environment and Africans as carriers of infectious agents, and how this produced a medical knowledge that led to the stigmatisation of both the environment and the indigenous urban poor. Epidemic outbreaks of diseases, but especially outbreaks of endemic yellow fever, provided the most important justification for the forced removal of the poor from the city centre, and eventually from the entire islandcity.

\section{Urban Landscapes: Disease, Sanitation, Lifestyles and Building Codes}

Colonial urban segregation was based on several strategies involving overlapping notions from medical knowledge regarding disease, urban strategies of hygiene and sanitation, sociocultural ideas about lifestyles, and technocratic principles involving building codes. Scholarship in the last three decades has especially shed light on the role of epidemic and endemic diseases in shaping the processes of urban planning, including the location and sustainability of a city, and particularly how diseases were used in the rationalisation of urban segregation. Most studies have focused on yellow fever, malaria, bubonic plague, cholera, smallpox and the influenza pandemic. This research has produced situated studies of colonial cities from across Africa in relation to disease outbreaks and their corresponding strategies of urban segregation. 
eTropic 20.1 (2021) Special Issue: Pandemic, Plague, Pestilence and the Tropics

Using the evidence drawn from across the continent, Philip Curtin argued that although malaria provided the most important argument for segregation, yellow fever and other diseases also played a role (Curtin, 1985). In the regions of West Africa, Christophe Wondji studied how recurrent outbreaks of yellow fever in Grand-Bassam, the capital of the French Côte d'Ivoire, between 1899 and 1903, led the colonial authorities to move the entire capital to Bingerville (Wondji, 1972). Studies of Freetown, the capital of Sierra Leone under British colonial rule, have shown that the perception that Europeans were at considerably higher risk than other races of contracting malaria and dying, weighted heavily in the decision to create the Hill Station area as an exclusive colonial residential space. The decision was not purely medical, but translated the racial thinking of the time (Frankel \& Western, 1988). In another study of Freetown, Odile Goerg argued that the transition from miasma theory to germ theory in the early twentieth century resulted in the stigmatisation of individuals or groups believed to be responsible for the multiplication of mosquitoes in the capital - the colonial authorities blamed the Africans for it, while the Creoles suspected the new migrants to the city (Goerg, 2015). In her earlier study of Conakry, the capital of Guinea, she demonstrated that the division of the city into zones and the creation of "une ville européenne" (a European city) resulted in a de facto segregation based on racialised classes (Goerg, 1998).

The spread to some colonial cities of the third great bubonic plague pandemic, which originated in subtropical Yunnan in southern China in 1894 before striking the rest of the world, provided an opportune justification for the implementation of segregation based on rationalisations of hygiene and sanitation. Let us start with South Africa. In a seminal article, Maynard W. Swanson has shown how the outbreak of bubonic plague in Cape Town and Port Elizabeth between 1900 and 1909 led local authorities to identify the plague with the African population and to implement racial residential segregation (Swanson, 1977). Swanson has also examined several factors which contributed to the implementation of segregation in Durban between the 1870s and 1900, these included: the threat of cholera and smallpox, the fear of competition for jobs and for trade against the Indians, and anti-black racism (Swanson, 1983). Other studies of sanitary segregation include Skotnes-Brown's exploration of the relation between human-animal health in the context of bubonic plague outbreaks in South Africa (Skotnes-Brown, 2020). Howard Philip has identified the linkages between the 1918 influenza pandemic and the furthering of discriminatory residential segregation laws (Philip, 1990). Harriet Deacon's study of racial segregation in Cape Town, South Africa, contended that medical and scientific discourses played an important role in making the case for urban segregation (Deacon, 1996). And finally, Bill Freund has compared the process of segregation in Durban, South Africa, and Abidjan, Côte d'Ivoire (Freund, 2001). 
eTropic 20.1 (2021) Special Issue: Pandemic, Plague, Pestilence and the Tropics

In West Africa, Raymond Betts has demonstrated that the 1914 bubonic plague epidemic in Dakar, Senegal, helped accelerate the policy of urban residential segregation, which was already discussed in 1901 in the context of anti-yellow fever measures (Betts, 1971). Thus the plague provided a justification for segregation which was already desired on racial grounds. Elikia Mbokolo has examined the link between the outbreak of bubonic plague in Dakar in 1914 and the implementation of notions of sanitary segregation (Mbokolo, 1982). Spencer H. Brown has described the poor sanitary conditions in Lagos that forced the municipal authorities to look for a healthier site for a European settlement outside the city (Brown, 1992). Myron Echenberg has revealed how the anxiety associated with urban expansion and its effects on sanitation, rather than epidemiological concerns, inspired the French colonial administration's response to the 1914 bubonic plague epidemic in Dakar (Echenberg, 2002). Liora Bigon has examined the impact of anti-bubonic plague practices on colonial urban planning policies in Dakar in 1914, Lagos in 1924, and Kumasi in 1924 (Bigon, 2016). Ngalamulume has shown how the French authorities identified the 1917 bubonic plague epidemic in Saint-Louis with the poor residents of the Guet-Ndar slum, declared a state of emergency based on unsanitary conditions, and evacuated all the slum residents (Ngalamulume, 2006).

Across the continent in East Africa, Dar es Salaam in colonial Tanganyika (present day Tanzania) was the focus of Sarah Smiley's study, which showed how a German colonial report noted that malaria was endemic to all areas of the city, including European residential neighbourhoods, and that hygiene measures such as draining areas would not eradicate the problem; thus, in this instance, racial segregation was not solely based on medical arguments to do with disease or on practices of sanitation, but were embedded within constructions codes which prepared the ground for the policy of social segregation, instigated under German colonialism and continued by the British colonial administration (Smiley, 2009).

Although this list is not exhaustive, the scholarship has greatly contributed to our understanding of the ways in which medical knowledge framed the understanding of the disease environment and how such an understanding stereotyped the Africans as carriers of, and more resistant to, disease and inspired segregationist schemes. Yet, little is known about the factors that provided the justification for residential segregation in Saint-Louis, Senegal. This article will focus on the ways in which the colonial doctors conceptualised Senegal, and Senegambia, ${ }^{1}$ as a tropical land full of dangers, stigmatised the Africans as

\footnotetext{
${ }^{1}$ Senegambia comprises the tropical zone between the Sahel and the Guinea forests, and is geographically bound by the Senegal and Gambian Rivers. It includes Senegal, Guinea-Bissau, The Gambia, and parts of Mali, Mauritania and Guinea.
} 
eTropic 20.1 (2021) Special Issue: Pandemic, Plague, Pestilence and the Tropics

carriers of pathogens and thus a threat to the Europeans' health, and framed outbreaks of yellow fever epidemics as the key justification for the removal of the urban poor from the city centre. Sanitary segregation was desired by the colonists on social (racist) grounds, but due to the specificity of the city's history, its implementation was along lines of (racialised) class.

\section{Saint-Louis-du-Sénégal}

Figure 1. Saint - Louis en 1854



Source: Faidherbe, L. (1889). Le Sénégal. La France en Afrique Occidentale (p. 76). Paris, Librairie Hachette Et Cie. Retrieved from Schomburg Center for Research in Black Culture, Jean Blackwell Hutson Research and Reference Div. The New York Public Library https://digitalcollections.nypl.org/items/510d47dc-83bf-a3d9-e040-e00a18064a99

Saint-Louis started as a fishing village inhabited by the Wolof fishermen on the Ndar Island near the mouth of the Senegal River. French merchants opened a trading post on the island in 1659. On the west side, the small arm of the Senegal River separates the island from a strip of land called Langue de Barbarie, which connects Saint-Louis to the continent and where two neighbourhoods were erected: Guet Ndar in the south and Ndar Toute in the north. The big arm of the Senegal River separates Saint-Louis Island from 
eTropic 20.1 (2021) Special Issue: Pandemic, Plague, Pestilence and the Tropics

Sor Island where the two villages of Bouetville and Sor would later stand. French merchants transformed Saint-Louis into a central place in a triangle of international trade that connected southern France to West Africa and the Caribbean. It became the capital of colonial Senegal (and of Mauritania until 1946), and, for a few years, the capital of French West Africa. Unions between Frenchmen and African women gave rise to a métis (biracial) community who would play an important role in commerce, politics, and liberal professions (Brigaud \& Vast, 1987; Zuccarelli, 1987; Bornadel, 1992; Sinou, 1993; Dozon, 2012; Ngalamulume, 2012; Jones, 2013). In the mid-nineteenth century, the coexistence between whites, blacks, and métis began to be questioned as the hygienic conditions, seasonal allergies from dusty air and moulds (depending on the tropical wet or dry seasons), and endemic and epidemic diseases worried the administration.

\section{Production and Reproduction of Medical Knowledge}

The challenge posed by the hot tropical climate, the epidemic and endemic diseases, as well as seasonal allergies, helped increase the visibility of the French colonial doctor in Saint-Louis. He (they were all men) possessed medical authority and competence, and reproduced, articulated, and circulated the medical knowledge produced in France. Medical knowledge reproduced in a colonial situation comes under the rubric of 'colonial medicine', and colonial medicine was in turn a branch of "colonial science" - an expression used by French sociologist Pierre Bourdieu to designate all the producers and scientific productions in colonial situations dependent on the local colonial power but relatively autonomous from "metropolitan science". The colonial medical discourse would borrow from the colonial discourses of anthropology (on otherness and the inequality of races), psychology (on primitive mentality), geography (on the environment, the "tropics"), linguistics (languages and dialects), history, ethnology and sociology (on cultures), and law (on legal dualism) (Singaravélou, 2011, p. 25). The French colonial doctor, thus, had a considerable scientific capital, which stemmed not only from the academic credentials granted by the Navy schools of medicine at Brest, Cherbourg, and Toulon, as well as by the civilian schools of medicine in Paris, Montpellier, and Bordeaux, but also from the Colonial Science Academy, the Paris Geographical Society, and the Collège de France. In the face of the constant challenge from the hot climate and diseases (especially malaria, yellow fever, dengue fever, and smallpox), such scientific capital would be deployed and reproduced within an increasing number of health boards: the Council of Council of Hygiene and Public Salubrity established in 1867; the Hygiene Commission in 1874; the Permanent Sanitary Co., 1881; the Municipal Sanitary Co., 1884; and the Municipal Hygiene Service, 1905. These were Presided over by Chief Medical Officers, 
eTropic 20.1 (2021) Special Issue: Pandemic, Plague, Pestilence and the Tropics

the General Secretary of the Government or an Interior Director. (Moniteur du Sénégal et Dépendances, 1867-1887; Bulletin Administratif du Senegal, 1905.)

Colonial doctors' voices were predominant on these health boards, which examined the epidemiological situation in the colony and made recommendations concerning the appropriate sanitary measures to be adopted. Most of the health boards were presided over by the Chief Medical Officer (médecin en chef) and included the mayor, two additional doctors, the Chief pharmacist, the hospital administrator, the engineering service Chief, the veterinarian of the Spahi troops, the port captain, and two local notables (one négociant [merchant] and one property owner). Due to their composition, these health boards operated under pressure from external political and economic constraints, which reduced their autonomy. Although the doctors' voices within these health boards was preponderant, the final recommendations from their deliberations often represented a compromise between the interests of public health and those of commerce and civil liberties.

The outbreaks of great yellow fever epidemics in 1867, 1878, 1880-81, and 1900 offered the colonial doctor the opportunity to construct medical knowledge that underlined the dangers of the tropical climate and the local environment, the differential susceptibility of different "races" to different diseases, and the possibility of "acclimatisation". The theory of acclimatisation was developed by Dr Jean-Christian-Marc Boudin. The main topics discussed in his work included medical meteorology and geology, statistical laws of the population and mortality, the geographical distribution of diseases, and the comparative pathology of human races. His theory of acclimatisation explored the possibility, variability, or flexibility of organisms to adapt to different climatic conditions (Boudin, 1857). The theory had practical applications in several domains, including agriculture, settlement schemes, sport, and human health. With reference to the colonial situation, the understanding was that it was possible for individuals and "races" to adapt to tropical climate through limited "seasoning", appropriate lifestyles, diet, hygiene, and medicine. His work posed the central problem of the colonies and became "the paradigmatic colonial science" (Osborne, 2000). It weighted heavily on climatic determinism, which precluded a good understanding of diseases, such as malaria (Anderson, 1992, pp. 135-157; Harrison, 1996; Dunlap, 1997; Bankoff, 2001; Last \& Porta, 2018; Minar, 2019).

These ideas about the dangers of the tropical climate and the possibility of adaptation dominated the French medical thinking in Saint-Louis, a city that was characterised since its beginning by the coexistence between whites, blacks from "good families" (the middle class), the métis, and the urban poor (indigènes). Beginning in the mid-nineteenth 
eTropic 20.1 (2021) Special Issue: Pandemic, Plague, Pestilence and the Tropics

century, the indigènes were blamed for throwing garbage, kitchen waste, and other rubbish in the streets, public spaces, along the docks, and on the banks of the Senegal River, which made an unbearable stench. Also, drying fish and using horses and mules for transportation resulted in the accumulation of waste matter in the streets. In addition, regular fires during the cold season (January-April) destroyed the urban poor's thatchedroofed huts, even in the city centre where three thousand huts, many of them contiguous to the houses inhabited by the French, the métis, and the black elite were located. There were other sources of tension, including begging and "noise" associated with childbirth, baptism, and marriage ceremonies. In 1856, Governor Louis Léon Faidherbe prohibited begging in the city by "a great number of strangers" as well as by the Koranic school students (talibés). Three years later, he undertook the forced removal of a group of indigènes from the city centre and destroyed 226 huts during an operation known as the "bataille de la paillotte" (war on shacks). In 1861, the operation continued and resulted in the destruction of the remaining eighty huts still standing in the city centre between SaintJean Street in the north and Ribet Street in the south, thus clearing fourteen streets of shacks (Moniteur du Sénégal et Dépendances, 1861).

\section{Environmental Factors and Human-Made Activities}

Yellow fever served as the most often used legitimisation for the forced removal of the urban poor from the city centre. During the first meeting of the Hygiene and Public Salubrity Council held on January 10 and 11, 1868 in the wake of the first great yellow fever epidemic, and presided over by the Chief Medical Officer, the participants were urged to: a) identify the causes of insalubrity in Saint-Louis and its neighborhoods and to make recommendations on how to eliminate them; $b$ ) to define the causes of the outbreak of the 1867 yellow fever epidemic and the appropriate means of preventing it from returning; and c) to examine the cemeteries located in the slums of Guet Ndar (for the Muslims) and Sor at the entrance of the Faidherbe Bridge (for the Catholics) and to recommend either their maintenance, enlargement, or removal from the city. The written questions submitted to the Council by the Ordonnateur [authorising officer] pointed to two secondary causes of yellow fever contained in the dominant epidemiological theory of the disease, including pestilential emanations (miasmas) from the two cemeteries and the unsanitary conditions (A.N.S./H20, 1868).

In their responses to the questions submitted by the Ordonnateur, the three doctors who dominated the debate within the Hygiene and Public Salubrity Council - Dr L. Huot, Dr Beaussier, and Dr Bancal - reproduced the medical knowledge elaborated in France and adapted it to the local situation. On the first day of their meeting, Dr Huot, Chief Medical 
eTropic 20.1 (2021) Special Issue: Pandemic, Plague, Pestilence and the Tropics

Officer, identified the rainy season (hivernage) during the hot summer months when the temperature reached 27 degrees Celsius, and stagnant water, as the primary causes of yellow fever - but their list also included other causes such as hygiene and sanitation, a lack of which was associated with the urban poor. The association of the rainy season (hivernage) with winter in Europe was justified by the fact that it was the most difficult and depressing season for the Europeans due to the rain. He explained that the areas of stagnant water everywhere in the city led to the decomposition of all sorts of organic matter, which secreted "pernicious emanations", the deadly poisonous vapour ("miasma"), that was perceived as a pathogen. Given the paucity of funds for the paving of the streets, he recommended the placement of bags of sand in different parts of the city that could be used to fill in areas of standing water. He also discussed the nature of the terrain in the south and east of the Sor slum, which was low and swampy, "with yellowish water where grew the mangroves and where the disease finds the telluric dispositions that contribute to giving it the terrible power that it has in these lands." $\mathrm{He}$ recommended the construction of a rainwater drainage canal (A.N.S./H2O, 1868).

Dr Huot also mentioned secondary causes of yellow fever. The "filth of the indigènes" was discussed at great length. While acknowledging the lack of a waste management service, doctors blamed the urban poor for leaving garbage lying on the ground, on the streets, and on the docks. They discussed the situation of unsanitary houses where cases of yellow fever and deaths were reported and recommended to sanitize, fumigate, and whitewash them, and to take similar measures for the objects that belonged to the victims of yellow fever. Other unsanitary houses that needed to be disinfected included some stores that contained dry cow skins, the slaughterhouses, and depots with greasy substances. The theory behind this laundry list was (contingent) contagionism. Doctors emphasised the "essential" difference between Europeans and Africans as follows:

If one sometimes finds the factors of insalubrity in the houses where the Europeans lived, what are we to think of the huts inhabited by the indigènes? There is no doubt among the members of the Council that if we were to ask of the inhabitants of these shacks a bit more cleanliness on their bodies, under their thatched roofs and in their interior courts, we would increase the chances of salubrity of the country (A.N.S./H 20, 1868).

Concerning the issue of unsanitary houses, the Council members recommended the implementation in Senegal of the legislation relative to the sanitation of insalubrious houses that was already in effect in France (the law of 13 April, 1850), and created a 
eTropic 20.1 (2021) Special Issue: Pandemic, Plague, Pestilence and the Tropics

permanent Hygiene Commission that would enforce the cleanliness of houses. If they expected the Europeans to comply with the new regulations related to home visits, they anticipated more resistance from the indigènes who, in contrast, were expected to refuse access to their dwellings. In the process of creating new laws and commissions, the Council members were constructing the Europeans as sanitary citizens and the indigènes as unsanitary subjects, and thus preparing the ground for their eventual forced removal. They saw the urban poor's huts as "the ideal ground for receiving the germ of the disastrous scourge" (A.N.S./H 20, 1868).

Another preoccupation of the Council members was the lack of fresh drinking water in Saint-Louis during the dry and cold season (January-April) when the absence of rain lowered the level of the Senegal River surrounding the city and allowed the influx of the salty ocean. This prompted the colonial administration to distribute to civil servants and the military four litres per day of fresh drinking water collected from upstream and stored in cisterns. Doctors concluded that the unclean drinking water, the climate, and the soil formed "a fatal triad to the European", thus affirming the differential susceptibility of whites and blacks to different diseases (A.N.S./H 20, 1868).

During the second meeting of the Hygiene and Public Salubrity Council, the next day on January 11,1868 , the three doctors determined that although the previous year's yellow fever epidemic was imported to Saint-Louis, it nevertheless found locally "the necessary conditions for taking on the disastrous character that its passage showed" (A.N.S/H 20, 1868). They again elaborated on the local conditions in question, including the topography of the land, the frequent breezes from the south, the two cemeteries located in the slums of Guet-Ndar and Sor, and the repulsive "pestilential emanations" they released. In their analysis, these local conditions of Saint-Louis helped explain the high mortality rate observed during the previous epidemic. This discussion of the causes of the outbreak of the 1867 yellow fever epidemic underlined a division between contagionists who supported the theory of the external origin of the disease, and the localists who insisted on the preponderance of the local environmental conditions in disease production. However, in practice, this division was not as entrenched as it might sound. All depended on the specific local circumstances (A.N.S./H 20, 1868).

The following recommendations they listed suggests that the Council members had made a correct observation by associating the rainy season with the outbreak of yellow fever, even if they did not draw a connection with the multiplication of mosquitoes. These recommendations stipulated that before the arrival of hivernage, the colonial administration had to confine the European troops to their garrisons, to isolate the sick 
eTropic 20.1 (2021) Special Issue: Pandemic, Plague, Pestilence and the Tropics

and the convalescents, and to increase hospital bedding. Of importance to urban planning and the city landscape, the Council members urged the immediate closure of the Catholic cemetery in Sor with the interdiction to use that space for other purposes for seven years; the creation of the new (Catholic) cemetery east of Bouetville on Sor Island at the entrance of Paris Street, with a capacity of 2,100 tombs; the closing of the Muslim cemetery located south of Guet-Ndar and the opening of a new Muslim cemetery in the northern part of Guet-Ndar slum two kilometers from the closest huts, with a capacity of 5,300 tombs. A keeper would maintain it. The administration also spent 6,000 francs to drain the stagnant water (A.N.S./20, 1868).

In 1873 the forced removal of the indigènes from the city centre continued to include the Saint-Paul Street in the north and the Saint-Joseph Street in the south (A.N.S., 1973, 1). And the authorities continued to complain about the filthy state of the Bouetville and Sor slums. Filth mainly from animal excrement was associated with the daily presence of a great number of cows and sheep in the area, but Mayor Brochet of Saint-Louis (1872-75) admitted that there was nothing he could do about it (A.N.S./H 20,1874).

Dr L-J. B. Bérenger-Féraud who served as the Chief Medical Officer in Saint-Louis between May 1871 and November 1873, reaffirmed the theory that yellow fever was an imported disease and that (the) climate, (the) topography, and individual physiological and pathological factors constituted only the "secondary causes". He described the climate of Senegambia as "insalubrious" and detrimental to the health of Europeans due to its location in the intertropical zone, with two seasons, one hot and humid (rainy) and the other cold and dry, and because of the influences from the Sahara Desert and the Atlantic Ocean. He affirmed that what was "different" about the topography of Senegambia was its salty clay soils (Bérenger-Féraud, 1878, pp. 325-53). In 1875, Dr A. Borius, a member of the Meteorological Society of France, also insisted on the strong correlation between the changing seasons and the emergence of weather-related diseases and allergies (Borius, 1875; 1879).

The 1878 yellow fever epidemic, which struck Saint-Louis during the hivernage months between mid-May and November, occurred in a city where residents had created vast problems of housing, waste, sewerage, and water supply and increased the quantity of breeding places for mosquitoes. By December, yellow fever had killed 652 Frenchmen out of a European population of 1,300 and an undetermined number of black residents. Such high mortality, and the anxiety associated with it, supported the authorities in their conviction that the separation between the Europeans and the indigènes was "an element 
eTropic 20.1 (2021) Special Issue: Pandemic, Plague, Pestilence and the Tropics

of first importance from the point of view of hygiene", and that necessary steps were needed to implement the policy of segregation in new cities to be constituted in the future.

The "sanitation syndrome" (Swanson, 1977) characterised the responses of the colonial authorities to the 1878 great yellow fever epidemic, which provoked high mortality among the European population. They became concerned with the presence of herds of cows in the city, and with the horses and mules used for transport, and their stinking excrement. By May 1879, the authorities became nervous, partly because of the approaching rainy season and partly because of an influx into Saint-Louis of hundreds of European troops. On May 13, 1879, the Military Hospital director alerted the governor about the danger represented by the indigenous fishing industry that he described as a "foyer of infection" (A.N.S./H 22, 1879). His alert prompted the administration to convene an urgent meeting the next day. The Sanitary Commission, chaired by Pierre Carpot who represented the colonial administration, met to discuss new cases of diarrhoea accompanied by fever and vomiting. Dr Doué, Acting Chief Medical Officer, explained that the smoke reported by three officers crossing the Servatius Bridge was coming from the Guet-Ndar slum and that it was offensively smelly, and that it gave them nausea. He added that similar symptoms (fevers, diarrhoea, and vomiting) were reported among the troops in the garrison and the Europeans in the city. Pierre Carpot blamed Gaspard Devès, the mayor of Saint-Louis, for tolerating the large scale drying of fish in Guet-Ndar and for his unwillingness to implement the sanitary measures taken in 1873 and 1878 concerning the designation of one fish drying ground at the extreme south of the slum. Mayor Gaspard Devès vigorously rejected Carport's accusations against his administration and informed the participants that the Municipal Council had already decided a year earlier (in 1878 ) to prohibit the drying of fish during hivernage between June and November. He also contested Dr Doué's framing of the disease as caused by the smoke from the drying of fish in Guet-Ndar. A vote at the end of the debate resulted in a majority in favour of a ban on the drying of fish starting on 1 May of every year (A.N.S./H 22, 1879).

The anxiety about the hot rainy season (hivernage) was so overwhelming that, in the wake of the 1878 yellow fever epidemic, in addition to repatriation plans for the unnecessary personnel, Governor General Brière de l'Isle required the European personnel working outdoors to wear straw or felt wick hats "to preserve their temples and the neck" (A.N.S./H 32/17, 1880). Segregation, the authorities realised, could not apply to the existing capitals, such as Saint-Louis, Dakar, or Conakry, where it would not find supporters among the merchants who were primarily concerned with profit, not hygiene. However, further outbreaks of yellow fever epidemics would force them to enact 
eTropic 20.1 (2021) Special Issue: Pandemic, Plague, Pestilence and the Tropics

segregation measures within Saint-Louis in the sense of driving the indigènes out of the city-island (A.N.S./H 32/14, 1881).

When "one of the most terrible" yellow fever epidemic outbreaks struck the city in late July 1881, it killed 503 Frenchmen, including Governor de Lanneau (A.N.S./H 32/14, 1881). The authorities again focused their attention on the local sanitary conditions. The Hygiene Commission admitted that "a great number of houses in Saint-Louis have a justified reputation for insalubrity" because of repeated deaths from yellow fever reported there every year. Owners of those houses were required to whitewash their homes and to fumigate the objects that had been in contact with the sick and the deceased (A.N.S., Hygiene Commission, 1881). They mobilised the Police Commissioner for the supervision of the sanitation operations in the city (A.N.S./H 32/10, 1881). The Director of Political Affairs even requested that the chiefs of the Guet-Ndar, Ndar Toute, and Bouetville slums contribute to the sanitation efforts with twenty residents each, but there was little enthusiasm from the latter (A.N.S./H 32/11, 1881). The authorities were also preoccupied with overcrowding and the interaction between people and animals, which they saw as the breeding ground for the outbreak of the 1881 "terrible" yellow fever epidemic that they perceived as the prolongation of the 1878 epidemic (Ngalamulume, 1996, p. 129). The Hygiene and Public Salubrity Council members who met on September 7, 1881 focused their attention on the cemeteries in the two slums surrounding the city and described them as a "permanent danger" to the city residents' health because of the "infectious emanations" that the tombs released. They proposed three solutions to the problem: a) to use six layers of materials to cover the old tombs (in the order of lime, sand, smashed charcoal, sand, lime, and clay) and five substantial layers for the new tombs (lime, sand, smashed charcoal, sand, and lime), while knowing that the administration had to order charcoal from France; b) to dig the tombs deeper where the soil allowed a 1.5 metre depth; and c) to simply the merge two cemeteries into one. The last proposed solution reflected a lack of cultural sensitivity from the participants who did not anticipate the possibility of conflicts when Catholic and Muslim burial rituals would be performed sometimes simultaneously (A.N.S./H 2, 1881).

The consensus among health officials was that once imported in 1878, yellow fever became endemic to Senegal. The evidence suggested that after the 1878 urban form of yellow fever subsided, the disease spread into the countryside probably following the movement of troops, traders or other city residents who had fled the city while incubating the disease. Thus, the later 1880-81 outbreaks in Senegal were considered a transformation from a now endemic to an epidemic disease. The 1880-81 urban epidemic probably started in Saint-Louis, as the Aedes aegypti, the yellow fever mosquito that had 
eTropic 20.1 (2021) Special Issue: Pandemic, Plague, Pestilence and the Tropics

adapted to breeding in the city, spread the virus as a specific urban outbreak different from the jungle form of yellow fever. The resultant epidemic caused 80 deaths in 1880 (Annales du Sénégal, 1881, p. 55).

In his comprehensive post-epidemic report, the Chief Medical Officer had a ready-made list of epidemic 'culprits'. First, he indicated that the "two factors that played a role in the production and reproduction of the disease" included the climate of Senegambia, with its high June-July temperatures reaching 27 degrees Celsius, and heavy rainfall averaging $668 \mathrm{~mm}$ that resulted in stagnant waters forming "large ponds" in the northern part of the city. Second, he noted the garbage and household wastes that polluted the banks of the Senegal River. And third and lastly, the doctor's report delved into the thorny issue of "crowded houses". He explained that the houses inhabited by the Europeans were surrounded by numerous huts belonging to the indigènes "to whom cleanliness was far from being a virtue and private hygiene was an empty word", adding that blacks shared their huts with domestic animals (A.N.S./H 32/14, 1882, p. 4). He enumerated other "secondary causes" of the now endemic yellow fever, including the location of the cityisland near the mouth of the river; a city barely above sea level with a relatively large population; organic matter, mainly of animal origin, in the yellowish water; constantly high temperatures, heavy humidity, abundant rains, and stagnant water during hivernage. In his view, all these factors formed an "electric surcharge", which helped explain the transition of yellow fever from endemicity to epidemic disease outbreaks (A.N.S./H 32/14, 1882, p. 4).

The Chief Medical Officer also recognised that there were two approaches to the threats posed by yellow fever, one emphasising the external origin and the other giving primacy to the local origin of the disease. The defenders of the external origin of yellow fever (the contagionists) recommended a surveillance program that enforced quarantine regulations targeting incoming ships, even if they also believed that local hygienic conditions played a role in the incidence of yellow fever. The defenders of the local origin of yellow fever (the localists) favoured sanitation and hygiene enforced by serious municipal police, the isolation of troops, the construction of docks, increased fines for non-compliers, the provision of safe drinking water, and (more importantly) "the removal of the indigènes' huts from the city centre first, and their progressive relocation to outside of the city-island" (A.N.S./H 32/14, pp. 14-15). The central administration in Paris considered both approaches, as the issuance of a few critical new pieces of legislation suggests. The implementation of the laws of 19 January, 7 March, and 13 April 1850 related to unsanitary housing, which was until then implemented in France, addressed the concerns of the localists and supporters of the residential segregation (Moniteur du Sénégal, 1882, 
eTropic 20.1 (2021) Special Issue: Pandemic, Plague, Pestilence and the Tropics

182) by underlining the unsanitary conditions of the overcrowded houses, which were viewed as "one imminent and fatal cause" of the reemergence of yellow fever (A.N.F.S.O.M./ XI/ d. 41, 1882). The authorities also prohibited the fishermen from drying fish in the city's slums between 1 June and 15 December (Bulletin Administratif, 1885, pp.164-5). Another piece of legislation organised the quarantine stations (Bulletin Administratif, 1885 , p. 488-490). Due to pressure from merchants, the automatic quarantine was lifted in 1897 despite the doctors' fear that the return of the yellow fever epidemic would provoke the ruin of the colony. The merchants argued that the quarantine regime was incompatible with the "new science," thus referring to the bacteriological revolution, which provided a scientific basis for the adoption of new public health measures concerning the vector control and the prevention of diarrheal diseases. Indeed, doctors in Senegal had ignored the role of the stégomya mosquito in the transmission of yellow fever, demonstrated in 1881 by Cuban physician Carlos (first and second name). In addition, the connection made in 1897 by British medical doctor Ronald Ross between the anopheles mosquito and the transmission of malaria called for the destruction of the vector (mosquito), changes to the environment (clearing of swamps and street cleaning), and the isolation of infected persons (Mathis, 1993, pp. 122, 142-4). However, the application of this germ theory in Senegal only gained momentum in the wake of the 1900 yellow fever epidemic.

\section{The Application of the Germ Theory}

When yellow fever re-emerged in Senegal in May 1900, the news provoked fear and panic, prompted the repatriation of non-essential personnel back to France, and the flight of hundreds of other Europeans, including the Governor General E. Chaudié. The embarrassment of the situation after yellow fever subsided weighted in the decision made by the central administration in Paris to send a sanitary mission of inquiry to Senegal between February and March 1901.

The Sanitary Mission's overall report re-affirmed "the true origin" of yellow fever as an imported disease and that heat, humidity, and contagion were only secondary and aggravating conditions. The report underlined the differential mortality between specific groups of people in terms of "partial adaptation of different groups" to specific climatic conditions, such as hot dry air and night cooling, and the differential susceptibility of racial and ethnic groups to different diseases. Drawing from the official statistics, the report indicated that mortality due to yellow fever was almost zero among the indigènes, relatively low among the Syrians, and high among the Moroccans, especially the newcomers. The report emphasised the fact that the "indigenous races and those who 
eTropic 20.1 (2021) Special Issue: Pandemic, Plague, Pestilence and the Tropics

are associated with them are the most dangerous because they offer exclusively benign symptoms that escape surveillance" (A.N.S./H 48/1, 1901, pp. 10-11). The members of the mission of inquiry were reiterating a long-held belief among the colonial authorities that Africans had already acquired disease-reducing immunity due to their primary exposure to the pathogens since childhood. The Africans were perceived to be dangerous in that their immunity did not prevent reinfection and did not reduce transmissibility, which helps explain why the authorities framed yellow fever as the "white man's disease" (Ngalamulume, 2012). The indigènes were also to blame for

The constant and secular pollution of the soil and of the urban atmosphere, (...) the inveterate habits of uncleanliness of the indigenous population living among the Europeans, the ignorance of the most elementary principles of hygiene regarding the removal of waste matters, (...) the insalubrity of most housing (...) (A.N.S./H 48/1, 1901). The report recommended, among other measures, surveillance of the fluctuating population (Moroccans, Syrians, crew members and passengers of ships or coasters) and of the indigènes who were in contact with the European population. Another measure related to urban hygiene urged the destruction of straw huts (A.N.S./H 49/57).

Dr E. Marchoux, one of the members of the Sanitary Mission who led the inquiry on urban hygiene, observed the presence of the unsanitary housing in some places in the cityisland. He was appalled by the sight of two slums with straw huts still standing in both the northern and southern parts of Saint-Louis, despite the issuance of successive ordinances for their forced removal from the city-island because of filth and the threat of fire that they posed. He also saw numerous wooden planks, many in bad shape and dirty, particularly in the northern and southern parts of the city-island, where "a very dense population lived willy-nilly with many animals, such as lambs, calves, pigs, etc. They were even more unsanitary than the straw huts that can be periodically replaced because of normal wear or fire" (.) The forced removal of the urban poor from the city-island and their relocation to Bouetville on Sor Island once the swamps were drained became imperative. Considerations of immunity also informed the suggestion made by $\mathrm{Dr}$ Grall that the African troops, "active carriers of the epidemic disease", be separated from the European troops (A.N.S./H 48/1, 1901).

The 1900 yellow fever epidemic also heightened the epidemic of fear and anxiety about the dangers of the hot climate of Senegambia for the bodies of the French. Insolation was one of the most feared threats. Two examples will suffice. On October 24, 1900, Administrator Deresac-Villagrand of the territory of Tivaouane (Senegal), reported that $\mathrm{Mr}$ Piollet, a Frenchman, died from insolation on October 21, 1900. He explained that four 
eTropic 20.1 (2021) Special Issue: Pandemic, Plague, Pestilence and the Tropics

days earlier, Piollet was transplanting lettuce in his garden with his back to the sun and his head down, which did not allow his helmet to protect his neck. The evening before his death, he got hot in his bed and went to a seat on the veranda near a window that had one broken tile. When he woke up the next morning, he was freezing and went to warm up in bed. Around noon, he developed frightening symptoms, including suffocation, congestion, delirium with rale, tetanic convulsion, and prostration. A "jet of blood streamed out of his nose, and a few moments later, he breathed his last." The administrator concluded that "Mr. Pollet did not die from an epidemic disease." Almost the same symptoms were observed concerning Mr Perfetti Mancherat and Mr Médus (A.N.S./H 42/140, 1900). Another feared condition was called "tropical anemia," which had the following symptoms: "Paleness of the skin, painful digestions, and vertigo associated with the defective functioning of the stomach and of the intestine, palpitations, breathlessness, [and] memory loss..." (Aubert, 1901, pp. 92-93),

The recommendations made by the members of the Sanitary Mission inspired reforms in the existing sanitary laws and emphasised the surveillance and rapid response to disease threats as well as a robust sanitation program initiated by the newly appointed governor general, Emile Roume, and continued by the Ponty administration. By 1902 the mosquito theory had gained acceptance in the light of the success stories coming from Cuba and Brazil and began to inform the sanitary laws and their enforcement, as well as the sanitation campaign. The new measures focused on the elimination of stagnant water, garbage, filth, discarded cans, vases, and containers around houses, and were enforced by agents who were sworn in and were authorized to penetrate inside private homes. The remaining indigènes still living in the northern and southern parts of the city-island became an easy target. They were known for their "old habits acquired over centuries", their "contempt for hygiene", and their "filthy dwellings" (A.N.S./H19, 1904), which made them particularly vulnerable to the provisions of the sanitary legislation related to unsanitary and dangerous buildings (A.N.S./H 19/10, 1904). Their dwellings did not respond to the new standards for safe housing (A.N.S./H 23, 1905, pp. 649-766). Since their huts could not be disinfected and were not appropriate for the installation of screens on the doors and windows, they were simply burned down and the indigènes were relocated to Sor Island (A.N.S./H 60, 1912). By 1912, the forced removal of the urban poor from the city-island was completed.

\section{Segregated Urban Landscape}

French doctors in Senegal conceptualised the Senegambian region as a diseased environment with its hot tropical climate and heavy rainfall that formed a breeding ground 
eTropic 20.1 (2021) Special Issue: Pandemic, Plague, Pestilence and the Tropics

for disease vectors, and its cold season that was filled with allergies. Doctors also defined the African urban poor as carriers of pathogens and blamed them for the unhygienic conditions of the urban environment. Doctors presided over most of the health boards which were created to examine the causes of epidemic diseases that posed serious threats to the operations of colonial administration and commercial activities, and to make recommendations to the municipal authorities. Other participants at the health board meetings represented competing interests and challenged or contested the doctors' opinions. Thus, the final recommendations to the colonial administration were often the result of a compromise between the interests of public health and those of commerce and civil liberties.

The early efforts to remove the urban poor from Saint-Louis' city centre started in the midnineteenth century under the governorship of Léon Louis Faidherbe and were justified as necessary to put an end to the "noise", begging, and regular fires that destroyed the urban poor's straw-roofed huts. The evidence presented here suggests that waves of yellow fever epidemic between 1867 and 1900, due of the high mortality and panic that they provoked, provided the strongest justification for residential segregation based on (racial) class - which was already desired by the colonials on social grounds. Given the history of racial mixing in Saint-Louis, in the application of segregation exception was made for the métis and blacks from "good families" - leaving the urban poor indigènes vulnerable to removal.

Saint-Louis was not alone. In the late nineteenth and early twentieth centuries, similar processes of marginalisation had accompanied outbreaks of epidemic diseases in other colonial cities in Africa and elsewhere throughout the tropics. The recommendations made by the Sanitary Mission in the wake of the 1900 yellow fever epidemic reaffirmed the credo of the differential susceptibility of different "races" and ethnic groups to various diseases and served to aid the 'contagionists' in their determination to pursue policies of segregration, as seen in the Sanitary 's insistence on the separation between European and African troops, and particularly inscribed upon the urban landscape with the forced removal of the urban poor indigènes from the city-island. 
eTropic 20.1 (2021) Special Issue: Pandemic, Plague, Pestilence and the Tropics

\section{References}

Archives Nationales du Senegal (A.N.S.), H Series.

Anderson, W. (1992). Climates of Opinion: Acclimatization in Nineteenth Century France and England. Victorian Studies, 35 (2), 135-157. https://www.jstor.org/stable/3828004

Aubert, E. (1901). Un peu d'hygiène coloniale. Les Annales coloniales, 11 (1), 92-93.

Bankoff, G. (2001). A Question of Breeding: Zootechny and Colonial Attitudes toward the Tropical Environment in the Late Nineteenth-Century Philippines. Journal of Asian Studies, 60 (2), 412-437. https://doi.org/10.2307/2659699

Betts, R. (1971), The Establishment of the Medina in Dakar Senegal, 1914. Africa, 41, 143-52. https://doi.org/10.2307/1159424

Bigon, L. (2016). Bubonic Plague, Colonial Ideologies, and Urban Planning Policies: Dakar, Lagos, and Kumasi. Planning Perspectives, 31 (2), 205-226. https://doi.org/10.1080/02665433.2015.1064779

Bornadel, R. (1992). Saint-Louis Du Sénégal : Mort ou Naissance ? Éditions L'Harmattan.

Borius, A. (1875). Recherches sur le climat du Sénégal. Gauthier-Villars.

Borius, A. (1879). Nouvelles recherches sur le climat du Sénégal. D'après les observations météorologiques faites pendant cinq ans (1874-1878). Ann. Bureau Central Météo.

Boudin, J.Ch.M. (1857). Traité de géographie et de statistique médicales et des maladies endémiques. J-B. Baillière et Fils.

Bourdieu, P. (1976). Les conditions sociales de la production sociologique : sociologie coloniale et décolonisation de la sociologie. In $\mathrm{H}$. Moniot (Éd.). Le Mal de voir. Ethnologie et orientalisme : politique et épistémologie, critique et autocritique (pp. 416-427). Union Générale d'Éditions.

Brigaud, F. \& and Vast, J. (1987). Saint-Louis Du Senegal. Ville aux Mille Visages. Editions ClairAfrique.

Brown, S.H. (1992). Public Health in Lagos, 1850-1900: Perceptions, Patterns, and Perspectives. The International Journal of African Historical Studies, 25 (2), 337-360. https://doi.org/10.2307/219390

Bulletin Administratif du Sénégal, 1905.

Coquery-Vidrovitch, C. (2008). The History of African Cities South of the Sahara. From the origins to Colonization. (Trans. By Mary Baker). Markus Wiener Publishers.

Curtin, P.D. (1985). Medical Knowledge and Urban Planning in Tropical Africa. The American Historical Review, 90 (3), 608. https://doi.org/10.2307/1860958

Deacon, H. (1996). Racial Segregation and Medical Discourse in Nineteenth-Century Cape Town. Journal of Southern African Studies, 22 (2), 287-308. https://doi.org/10.1080/03057079608708492

Dozon, J.-P. (2012). Saint-Louis du Sénégal. Palimpseste d'une ville. Karthala.

Dulucq, S. (1997). La France et les villes d'Afrique noire francophone : quarante ans d'intervention (1945-1985). Éditions L'Harmattan.

Dunlap, T.R. (1997). Remaking the Land, the Acclimatization Movement and Anglo Ideas of Nature. Journal of World History, 8 (2), 303-319. https://doi.org/10.1353/jwh.2005.0062

Echenberg, M. (2002). Black Death, White Medicine: Bubonic Plague and the Politics of Public Health in Colonial Senegal, 1914-1945. Heinemann.

Frenkel, S. \& Western, J. (1988). Pretext or Prophylaxis? Racial Segregation and Malarial Mosquitos in a British Tropical Colony: Sierra Leone. Annals of the Association of 
eTropic 20.1 (2021) Special Issue: Pandemic, Plague, Pestilence and the Tropics

American Geographers, 78 (2), 211-228. https://doi.org/10.1111/j.14678306.1988.tb00203.x

Freund, B. (2001). Contrasts in Urban Segregation: a Tale of Two African Cities, Durban (South Africa) and Abidjan (Côte d'Ivoire). Journal of southern African studies, 27(3), 527-546. https://doi.org/10.1080/13632430120074572

Goerg, O. (1998). From Hill Station (Freetown) to Downtown Conakry (First Ward): Comparing French and British Approaches to Segregation in Colonial Cities at the Beginning of the Twentieth Century. Canadian Journal of African Studies/Revue Canadienne des études africaines, 32 (1),1-31. https://doi.org/10.1080/00083968.1998.10751128

Goerg, O. (2015). Des moustiques et des hommes. Savoirs médicaux et relations intercommunitaires à Freetown (Sierra Leone) au tournant du XXe siècle. Ethnologie française, 45 (3), 445-454. https://doi.org/10.3917/ethn.153.0445

Harrison, M. (1996). The Tender Frame of Man: Disease, Climate, and Racial Difference in India and West Indies, 1760-1860. Bulletin of the History of Medicine, 70 (1), 68-93. https://doi.org/10.1353/bhm.1996.0038

Jones, H. (2013). The Metis of Senegal: Urban Life and Politics in French West Africa. Indiana University Press.

King, A. (1990). Urbanization, Colonialism, and the World-Economy. Cultural and Spatial Foundations of the World Urban System. Routledge.

Last, J.M. and Porta, M. (2018). Acclimatization. Ohio University Press.

Mathis, C. (1946). L'œuvre des Pastoriens en Afrique. P.U.F.

Maylam, P. (1995). Explaining the Apartheid City: 20 Years of South African Historiography. Journal of Southern African Studies, 21 (1), 19-38. https://doi.org/10.1080/03057079508708431

Mbokolo, E. (1982), Peste et société à Dakar : l'épidémie de 1914. Cahiers d'Études africaines, 22, 13-46. https://doi.org/10.3406/cea.1982.2272

Minar, P.M. (2019). All Things Harmless, Useful, and Ornamental; Environmental Transformation through Species Acclimatization, from Colonial Australia to the World. The University of North Carolina Press. https://doi.org/10.5149/northcarolina/9781469651613.001.0001

Moniteur du Sénégal et dépendances, 1867-1887.

Ngalamulume, K. (2006). Plague and Violence in Saint-Louis-du-Senegal, 1917-1920. Cahiers d'Études Africaines, 184 (3), 539-565. https://doi.org/10.4000/etudesafricaines.15301

Ngalamulume, K. (2012). Colonial Pathologies, Environment, and Western Medicine in SaintLouis-du-Senegal, 1867-1920. Peter Lang. https://doi.org/10.3726/978-1-4539-0813-6

Ngalamulume, K. (1996). "City Growth, Health Problems, and the Government Response," PhD dissertation, Michigan State University.

Singaravélou, P. (2011). Professer l'empire. Les " sciences coloniales » en France sous la Ille République. Publications de la Sorbonne.

Sinou, A. (1993). Comptoirs et villes du Sénégal : Saint-Louis, Gorée, Dakar. Karthala.

Smiley, S.L. (2009). The City of Three Colors: Segregation in Colonial Dar es Salaam, 18911961. Historical Geography, 37, 178-196.

Osborne, M.A. (2000). Acclimatizing the World. A History of the Paradigmatic Colonial Science. Osiris, 15 (1), 135-151. https://doi.org/10.1086/649323

Parnell, S., (1993). Creating Racial Privilege: The Origins of South African Public Health and Town Planning Legislation. Journal of Southern African Studies, 19 (3), 471-488. https://doi.org/10.1080/03057079308708370 
eTropic 20.1 (2021) Special Issue: Pandemic, Plague, Pestilence and the Tropics

Phillips, H. (1990). Black October: The Impact of the Spanish Influenza Epidemic of 1918 on South Africa. The Government Printer.

Poinsot, F., Sternadel, J. \& Sinou, A. (1989). Les Villes d'Afrique noire entre 1650 et 1960. La Documentation française. https://hal.archives-ouvertes.fr/hal-00701385.

Swanson, M.W. (1977). The Sanitation Syndrome: Bubonic Plague and Urban Native Policy in the Cape Colony, 1900-1909. The Journal of African History, 18 (3), 387-410. https://doi.org/10.1017/S0021853700027328

Swanson, M.W. (1983). The Asiatic Menace: Creating Segregation in Durban, 1870-1900. The International Journal of African Historical Studies, 16 (3), 401-421. https://doi.org/10.2307/218743

Wondji, C., (1972). La fièvre jaune á Grand-Bassam (1899-1903). Revue française d'histoire d'Outre-Mer, 59 (215), 205-239. https://doi.org/10.3406/outre.1972.1596

Zuccarelli, F. (1987). La Vie politique sénégalaise (1789-1940). CHEAM.

\section{Acknowledgements}

The archival materials used in this article were gathered in the Archives Nationales du Sénégal (A.N.S.) in Dakar, the Archives Nationales d'Outre-Mer (A.N.O.M.) in Aix-enProvence, and in the Bibliothèque Nationale François Mitterand in Paris. The research was assisted by grants from the Rockefeller Foundation and from the Joint Committee of African Studies of the Social Science Research Council and the American Council of Learned Societies with funds provided by the Ford, Mellon, and Rockefeller Foundations. I thank them all for their support. I also thank Professor Anita Lundberg very much for her invitation to contribute to the special issue of this journal and for her excellent copy-editing of this article. I am indebted to the anonymous reviewers of eTropics: electronic journal of studies in the tropics for their comments on the draft of this article.

Associate Professor Dr Kalala Ngalamulume is with History and Africana Studies at Bryn Mawr College in Pennyslvania, U.S.A. He is the author of several scholarly articles and book chapters on the social history of medicine, disease, and health in Senegal. He is also the author of Colonial Pathologies, Environment and Western Medicine in SaintLouis-du-Senegal, 1867-1920 (2012), and co-editor with Paula Viterbo of Medicine and Health in Africa: Multidisciplinary Perspectives (2010). He has published in the Journal of African History, Journal of West African History, Cahiers d'Études Africaines, Politique Africaine, History in Africa, African Economic History, Revue de Pédagogie Appliquée, Encyclopedia of African History, and Oxford Bibliographies Online. Kalala has a PhD in History, and an MA in International Affairs. 